\title{
THE IMPROVEMENT OF OBSERVATION REPORT WRITING SKILL THROUGH THE APPLICATION OF EXPERIENTIAL LEARNING MODEL (CLASSROOM ACTION RESEARCH IN THE FIFTH GRADE STUDENTS OF SURAKARTA STATE PRIMARY SCHOOL AT 2017/2018 ACADEMIC YEAR
}

\section{Sulistya Ardiani Kusumastuti, Yulianti, Endang Sri Markamah}

Universitas Sebelas Maret

sulistyaardiani@gmail.com

\section{Article History}

accepted 09/07/2018

approved 01/08/2018

published 17/09/2018

\section{Keywords}

experiential learning, the observation report writing skill

\begin{abstract}
The purpose of this research is to improve the observation report writing skill by applying Experiential Learning model. This form of research is a classroom action research conducted two cycles. Each cycles consist of two times and each times consist of four phases, they are planning, action, observation, and reflection. The data collecting technique are interview, observation, documentation, and test. The data validity technique og the research is content validity. The data analysis technique is interactive analysis model (Mile \& Huberman). The result of this research, shows that the application of Experiential Learning models that can improve the observation report writing skill. Applying Experiential Learning model appropritate with the teoritical study that the has been done for twi cycles could improve the skill of observation report writing skill by applying Experiential Learning model on the fifth grade students of Tegalsari No.60 Surakarta state primary school at 2017/2018 academic year.
\end{abstract}

Social, Humanities, and Education Studies (SHEs): Conference Series https://jurnal.uns.ac.id/shes 


\section{PENDAHULUAN}

Bahasa Indonesia telah tertuang dalam kurikulum secara garis besar mencakup empat aspek keterampilan berbahasa yaitu keterampilan menyimak, berbicara, membaca dan menulis. Keempat aspek tersebut merupakan satu kesatuan dalam berbahasa agar siswa memiliki kemampuan berkomunikasi secara efektif, menghargai dan menggunakan bahasa Indonesia sebagai bahasa persatuan, dan meningkatkan kemampuan intelektual (Tarigan : 2013)

Dengan penguasaan satu keterampilan yang telah dikuasai dengan baik maka akan mudah dalam menguasai keterampilan yang lainnya. Akan tetapi dalam penguasaan satu keterampilan tidaklah mudah, dibutuhkan adanya latihan atau pembiasaan sejak dini pada siswa SD. Keterampilan berbahasa yang sangat penting bagi siswa yaitu keterampilan menulis. Salah satu keterampilan menulis yang dipelajari dalam materi bahasa Indonesia adalah menulis laporan. Menulis laporan sangat berkaitan dengan laporan pengamatan maupun laporan tentang kunjungan wisata. Manfaat yang didapat ketika siswa menulis laporan yaitu menuangkan apa yang sudah dipikirkan dan dialami kedalam bentuk tulisan. Tanpa memiliki kemampuan menulis yang memadai sejak dini, siswa akan mengalami kesulitan belajar dikemudian hari. Keberhasilan siswa dalam mengikuti kegiatan pembelajaran di SD banyak ditentukan oleh kemampuannya dalam menulis. Maka dari itu, pembelajaran menulis mempunyai kedudukan yang strategis dalam pendidikan dan pembelajaran. Namun kenyataannya keterampilan menulis kelas V SDN Surakarta masih rendah.

Rendahnya keterampilan menulis laporan pengamatan siswa kelas V SDN Surakarta dibuktikan dari hasil dokumentasi, hasil wawancara, hasil observasi dan hasil tes pratindakan. Hal tersebut disebabkan peran guru sebagai fasilitator masih kurang terutama pada materi menulis laporan pengamatan. Terlihat dari hasil pratindakan bahasa Indonesia meteri laporan pengamatan yang telah dilaksanakan pada siswa kelas V SDN Surakarta tanggal 20 Januari 2018. Dari 21 siswa kelas V yang mengikuti tes, hanya 3 siswa yang dapat memenuhi KKM (Kriteria Ketuntasan Minimal) dengan presentase ketuntasan sebesar $14 \%$. sedangkan $86 \%$ atau 18 siswa lainnya belum memenuhi KKM. Rata-rata nilai yang diperoleh siswa kelas V SDN Surakarta yaitu 54 berdasarkan hasil pratindakan yang telah dilakukan siswa kelas $\mathrm{V}$ SDN Surakarta masih banyak yang belum menguasai materi menulis laporan pengamatan karena nilai yang didapat masih dibawah standar yang ditentukan.

Kebanyakan siswa mengalami kesulitan dalam menulis laporan pengamatan dikarenakan guru hanya menggunakan metode ceramah dalam menjelasakan langkah-langkah menulis laporan. Siswa hanya duduk diam memperhatikan penjelasan contoh laporan selanjutnya siswa langsung menjawab pertanyaan-pertanyaan yang disajikan. Dalam mengerjakan tugas menulis laporan pengamatan, tugas dikerjakan dirumah sehingga banyak dari siswa yang sekedar mengambil dari internet maupun dalam pengerjaan tidak adanya bimbingan dari guru.

Terkait belum optimalnya keterampilan menulis laporan pengamatan siswa kelas V SDN Surakarta, maka peneliti menerapkan model Experiential Learning. Hosnan (2014) mengungkapkan bahwa Experiential Learning adalah suatu proses belajar mengajar yang mengaktifkan pembelajaran untuk membangun pengetahuan dan keterampilan serta nilai-nilai, juga sikap melalui pengalamannya langsung. Kelebihan model pembelajaran Experiential Learning menurut Silberman (2015) yaitu berperan dalam proses perubahan pada pembelajaran antara lain dengan menciptakan keterbukaan atau membiarkan siswa mengembangkan kemampuan yang dimiliki dan memajukan pemahaman dengan siswa berfikir kirtis. Model pembelajarn Experiential Learning membantu terciptanya suasana pembelajaran yang kondusif, meningkakan semangat dan gairah siswa, membuat suaana pembelajaran nyata atau langsung dalam proses pembelajaran dan mengembangkan proses berfikir kreatif. 
Peneliti tartarik untuk menggunakan model pembelajaran Experiential Learning dalam pembelajaran menulis laporan pengamatan, karena model pembelajaran Experiemtial Learning menawarkan pembelajaran yang menekannkan pada proses pembelajaran aktif dan melatih siswa untuk membangun pengetahuannya sendiri berdasaran pada pengalaman yang telah didapat sehingga cocok digunakan dalam pembelajarn menulis laporan pengamatan dalam pelajaran Bahasa Indonesia untuk meningkatan keterampilan menulis laporan pengamatan melalui model pembelajaran Experiential Learning pada siswa kelas V SD Negeri Surakarta Tahun Ajaran 2017/2018.

\section{METODE}

Penelitian ini dilaksanakan pada siswa kelas V SDN Surakarta tahun ajaran 2017/2018 dalam kurun waktu delapan bulan dimulai dari bulan Desember 2017 hingga Juni 2018. Data yang dikumpulkan dalam penelitian ini berupa hasil observasi kinerja guru dan aktivitas siswa, hasil wawancara guru dan siswa, hasil tes pratindakan dan hasil tes pada setiap pertemuan pada siklus I, dan II, serta dokumentasi selama proses pembelajaran. Sumber data dalam penelitian ini yaitu sumber data primer dan sekunder. Teknik pengumpulan data yang digunakan yaitu observasi, wawancara, tes, dan dikumentasi. Validasi data yang digunakan yaitu validasi isi, triangulasi sumber dan teknik. Data yang diperoleh dalam penelitian ini dianalisis menggunkan model ineraktif Milles dan Huberman yang dilakukan dalam 2 siklus dengan masing-masing siklus terdiri dari 2 pertemuan. Setiap siklus terdiri atas 4 tahap yaitu perencanaan, tindakan, observasi dan refleksi.

\section{HASIL DAN PEMBAHASAN}

Berdasarkan hasil tes pratindakan keterampilan menulis laporan pengamatan sebelum diterapkannya model Experiential Learning menunjukkan bahwa sebagian besar siswa kelas V SD N Surakarta tahun ajaran 2017/2018 masih memperoleh nilai di bawah KKM (70). Hasil selengkapnya dapat dilihat pada tabel 1 sebagai berikut:

\section{Tabel 1. Hasil analisis Keterampilan Menulis Laporan Pengamatan Pratindakan}

\begin{tabular}{lcccc}
\hline Interval & $\begin{array}{c}\text { Frekuensi } \\
(\mathbf{f})\end{array}$ & $\begin{array}{c}\text { Nilai Tengah } \\
(\mathbf{x})\end{array}$ & $\mathbf{( f ) . ( x )}$ & $\begin{array}{c}\text { Presentase } \\
(\%)\end{array}$ \\
\hline $25-33$ & 1 & 29 & 29 & $4,8 \%$ \\
$34-42$ & 4 & 38 & 152 & $19 \%$ \\
$43-51$ & 4 & 47 & 188 & $19 \%$ \\
$52-60$ & 4 & 56 & 224 & $19 \%$ \\
$61-69$ & 5 & 65 & 325 & $23,9 \%$ \\
$70-78$ & 3 & 74 & 222 & $14,3 \%$ \\
Jumlah & $\mathbf{2 1}$ & & $\mathbf{1 . 1 4 0}$ & $\mathbf{1 0 0 \%}$ \\
Nilai rata-rata & $=54$ & & \\
Ketuntasan klasikal & $=14,3 \%$ & & \\
$\begin{array}{l}\text { Ketidaktuntasan klasikal } \\
\text { Nilai tertinggi }\end{array}$ & $=85,7 \%$ & & \\
Nilai terendah & $=75$ & & \\
\hline
\end{tabular}

Berdasarkan data diatas siswa yang belum mencapai kriteria ketuntasan minimal yang telah ditetapkan dari 21 siswa hanya 3 siswa atau $14,3 \%$ yang mencapai kriteria ketuntasan minimal dan 18 siswa atau $85,7 \%$ belum mencapai krieteria ketuntasan minimal. Dengan nilai terendah 25, nilai tertinggi 75, dan rata-rata kelas 54.

Setelah dirterapkannya model Experiential Learning dalam proeses pembelajaran, nilai keterampilan menulis laporan pengamatan pada siklus I mengalami peningkatan. Hasilna dapat dilihat pada tabel 2 sebagai berikut: 
Tabel 2. Hasil Analisi Nilai Keterampilan Menulis Laporan Pengamatan Siklus I

\begin{tabular}{ccccc}
\hline Interval & $\begin{array}{c}\text { Frekuensi } \\
(\mathbf{f})\end{array}$ & $\begin{array}{c}\text { Nilai Tengah } \\
(\mathbf{x})\end{array}$ & $\mathbf{( f ) . ( x )}$ & $\begin{array}{c}\text { Presentase } \\
(\mathbf{\%})\end{array}$ \\
\hline $55-60$ & 2 & 58 & 116 & $9,5 \%$ \\
$61-66$ & 4 & 63 & 252 & $19 \%$ \\
$67-72$ & 3 & 70 & 210 & $14,3 \%$ \\
$73-78$ & 5 & 76 & 380 & $23,9 \%$ \\
$79-84$ & 4 & 82 & 328 & $19 \%$ \\
$85-90$ & 3 & 88 & 264 & $14,3 \%$ \\
Jumlah & $\mathbf{2 1}$ & & $\mathbf{1 . 5 5 0}$ & $\mathbf{1 0 0 \%}$ \\
Nilai rata-rata & $=73$ & & & \\
Ketuntasan klasikal & $=67 \%$ & & & \\
Ketidaktuntasan klasikal & $=33 \%$ & & & \\
Nilai tertinggi & $=88$ & & & \\
Nilai terendah & $=55$ & & & \\
\hline
\end{tabular}

Pada silklus I diperoleh nilai rata-rata 73. Ketuntasan klasikal yang dicapai sebesar $67 \%$ atau 14 siswa yang mendaat nilai mencapai KKM dan $33 \%$ atau 7 siswa yang belum mencapai niali KKM. Nilai terendah 55 dan nilai tertinggi 88. Dari data tersebut dapat diketahui bahwa ketuntasan klasikal pada siklus I belum mencapa target pada indikator kinerja yaitu $80 \%$, maka penelitian dilanjutkan pada siklus II.

Pada siklus II nilai keteramilan menulis laporan pengamatan siswa kelas V SD N Surakarta tahun ajaran 2017/2018 menunjukkan adanya peningkatan kembali. Hasil nilai keterampilan menulis laporan pengamatan dapat dilihat pada tabel 3 . Sebagai berikut:

Tabel 3. Hasil Analisi Nilai Keterampilan Menulis Laporan Pengamatan Siklus II

\begin{tabular}{ccccc}
\hline Interval & $\begin{array}{c}\text { Frekuensi } \\
(\mathbf{f})\end{array}$ & $\begin{array}{c}\text { Nilai Tengah } \\
(\mathbf{x})\end{array}$ & $(\mathbf{f}) .(\mathbf{x})$ & $\begin{array}{c}\text { Presentase } \\
(\%)\end{array}$ \\
\hline $63-67$ & 2 & 65 & 130 & $9,5 \%$ \\
$68-72$ & 2 & 70 & 140 & $9,5 \%$ \\
$73-77$ & 3 & 75 & 225 & $14,3 \%$ \\
$78-82$ & 4 & 80 & 320 & $19 \%$ \\
$83-87$ & 6 & 85 & 510 & $28,6 \%$ \\
$88-92$ & 4 & 90 & 360 & $19 \%$ \\
Jumlah & $\mathbf{2 1}$ & & $\mathbf{1 . 6 8 5}$ & $\mathbf{1 0 0 \%}$ \\
Nilai rata-rata & $=80$ & & & \\
Ketuntasan klasikal & $=86 \%$ & & & \\
Ketidaktuntasan klasikal & $=14 \%$ & & & \\
Nilai tertinggi & $=92$ & & & \\
Nilai terendah & $=63$ & & & \\
\hline
\end{tabular}

Pada siklus II niali rata-rata 80 . Ketuntasan klasikal yang dicapai sebesar $86 \%$ atau 18 siswa yang mendapat nilai mencapai KKM dan 14\% atau 3 siswa yang belum mencapai nilai KKM. Nilai terendah 63 dan niali tertinggi 92. Hasil nilai keterampilan menulis laporan pengamatan pada siklus II meningkat dan telah mencapai indikator kinerja yaitu $80 \%$ dan siswa telah mencaai nilai KKM, oleh karena itu peneliti mengakhiri tindakan dalam pembelajaran menulis laporan pengamatan.

Hasil pelaksanaan tindakan setiap siklus maka dapat di simpulkan bahwa penerapan model Experiential Learning berhasil meningkatakan keterampilan menulis laporan pengamatan pada siswa kelas V SD N Surakarta tahun ajaran 2017/2018. 
Model Pembelajaran Experiential Learning juga berdampak pada peningkatan nilai kinerja guru serta aktivitas siswa dalam proses pembelajaran. Peningkatan nilai keterampilan menulis laporan pengamatan siswa kelas V SD N Surakarta melalui penerapan model Experiential Learning dapat dibuktikan dengan adanya peningkatan nialai rata-rata dan ketuntasan klasiskal pada setiap siklus.

Tes pratindakan keterampilan menulis laporan pengamatan, diperoleh nilai ratarata kelas 54, masih kurang dari yang telah ditetapkan. Sedangka presentase siswa yang nilainya tuntas hanya 3 siswa atau $14 \%$, sedangkan $86 \%$ atau 18 siswa lainnya masih belum memenuhi KKM. Nilai terendah pada tes pratindakan yaitu 25, sedangkaan nilai tertinggi yang diperoleh adalah 75 . Berdasarkan hasil analisis tes patindakan tersebut, indikator kinerja penelitia ( $80 \%$ atau 18 siswa) belum tercapai, maka dilakukan tindakan yang berupa penelitian tindakan kelas untuk meningkatkan keterampilan menulsi lapoaran pengamatan dengan menerapkan model Experiential Learning.

Pelaksanaan siklus I menerapkan model Experiential Learning dalam pembelajaran keterampilan menulis laporan pengamatan. Nilai ketuntasan klasikal mencapai $67 \%$ atau 14 siswa yang dapat mencapai nilai KKM dan $33 \%$ atau 7 siswa yang belum mencapai nilai KKM dengan nilai rata-rata kelas 73. Pada siklus II terjadi peningkatan yaitu ketuntasan klasikal mencapai $86 \%$ atau 18 siswa mencapai nilai KKM dan $14 \%$ atau 3 siswa yang belum menapai nilai KKM dan nilai rata-rata kelas 80 sehingga indikator kinerja penelitian telah tercapai apada siklus II.

Model Experiential Learning terbukti dapat meningkatkan keterampilan menulis laporan pengamatan. Peneran model Experiential Learning dapat mengembangkan proses berfikir kreatif siswa untuk mendorong menuangkan ide maupun gagasan dalam menulis (Hosnan, 2013). Sehingga siswa belajar untuk berfikir kreatif dalam memilih kosa kata yang tepat dalam menuyusun laporan pengamatan.

Peningkatan pada nilai keterampilan menulis laporan pengamatan siswa kelas $\mathrm{V}$ SD N Surakarta meningkat pula pada nilai rata-rata kinerja guru dan aktivitas siswa pada siklus I dan siklus II. Pada siklus I kinerja guru termasuk dalam kategori baik dengan skor rata-rata 2,7 dan meningkat pada siklus II menjadi 3,5 masuk dalam kategori sangat baik. Sama halnya dengan aktivitas siswa yang mengalami peningkatan dengan perolehan skor pada siklus I yaitu 2,7 masuk kategori baik dan meningkatat pada siklus II menjadi 3,6 masuk kategori sangat baik. Berdasarkan hasil tersebut menunjukkan bahwa siswa menjadi lebih aktif untuk berpartisipasi dalam pembelajaran keterampilan menulis laporan pengamatan. Peningkatan nilai keterampilan menulis laporan pengamatan siswa dengan diterapkannya model Experiential Learning juga berdampak pada peningkatan kinerja guru dan aktivitas siswa yang dapat meingkatkan partisipasi peserta didik (Hamruni, 2010).

Hal tersebut didukung oleh penelitian Diah (2017) yaitu penerapan model Experiential Learning untuk meningkatkan keterampilan menulis pantun pada siswa kelas IV SD N di Kabupaten Purworejo juga baik dan mengalami peningkatan. Pada hasil pratindakan ketuntasan klasikal yang didapat yaitu $26,1 \%$ kemudian meningkat menjadi $73,91 \%$ dan pada akhir penelitian presentase ketuntasan klasikal menjadi sebesar $96,65 \%$.

Oleh karena itu dapat dikatakan bahwa penerapan model Experiential Learning tepat dipergunakan untuk meningkatkan keterampilan menulis laporan pengamatan dan kualitas beajar pada siswa kelas V SD Surakarta tahun ajaran 2017/2018.

\section{SIMPULAN}

Berdasarkan hasil penelitian tindakan kelas yang telah dilaksanakan selama dua siklus dapat disimpulkan bahwa model Experiential Learning dapat meningkatkan keterampilan menulis laporan pengamatan pada siswa kelas V SD N Surakarta tahun ajaran 2017/2018 


\section{DAFTAR PUSTAKA}

Diah, Novia. (2017). Peningkatan Keterampilan Menulis Pantun Melalui Penerapan Model Experiential Learning pada Siswa Kelas IV SD Negeri di Kabupaten Purworejo Tahun Ajaran 2016/2017. Surakarta: UNS Press.

Hosnan. (2014). Pendekatan Saintifikdan Kontekstual dalam Pembelajaran Abad 21. Jakarta: Ghalia Indonesia

Tarigan. (2013). Menulis Sebagai Suatu Keterampilan Berbahasa. Bandung: Angkasa.

Silberman. (2015). Handbook Experiential Learning: Strategi Pembelajaran dari Dunia Nyata. Bandung: Nusa Media. 